\title{
IMPROVING YIELD AND YIELD QUALITY OF FOUR FABA BEAN CULTIVARS GROWN UNDER RAINFALLS 2- APPLICATION OF GROWTH REGULATORS*
}

\author{
Caser G. Abdel
}

Horticulture Dept., Agric. \& Forestry College, Mosul Univ., Iraq

\begin{abstract}
Four experiments were carried out at the research field of horticulture Dept, Agriculture \& Forestry college, Mosul University, during 2004-2005 growing season to investigate the ability of boosting drought resistance in four faba bean cultivars by foliar spraying of alar (B9) at rates of 0, 250, 500, 750 and $1000 \mathrm{mg}$. $\mathrm{L}^{-1}$; cultar (ppp3) at rates of 0, 50, 75 and $100 \mathrm{mg} \mathrm{L}^{-1}$; indole-3butyric acid (IBA) at rates of $0,50,75$ and $100 \mathrm{mg} . \mathrm{L}^{-1}$ and naphthalene acetic acid at rates of $0,25,50$ and $75 \mathrm{mg}$. $\mathrm{L}^{-1}$ at the commence of flowering and was repeated after 2 weeks. Experiment $1,250 \mathrm{mg}$. $\mathrm{L}^{-1}$ alar was the most effective treatment in enhancing drought resistance of Aquadulce cultivar. It increased yield of dry seeds $(52.8 \%)$. Furthermore, it improved stomata behaviors to sustain gas exchange good through increasing stomata populations and reducing their aperture dimensions. Experiment 2 results exhibited that $50 \mathrm{mg}$. $\mathrm{L}^{-1}$ cultar rate was the most suitable treatment for increasing drought resistance of Local Syrian cultivar. It gave dry seed yield increases of $48.4 \%$, in relation to check. In addition to that it highly modified stomata dimensions to improve gases exchanges. Experiment 3 results displayed that $75 \mathrm{mg} . \mathrm{L}^{-1}$ IBA rate applied on Babylon cultivar was the most potent treatment in relation to untreated treatment. It substantially increased the yield of dry seeds $(86.4 \%)$, when compared to untreated control. Finally, experiment 4 results revealed that the application of $25 \mathrm{mg} \cdot \mathrm{L}^{-1} \mathrm{NAA}$ on the determinate Taka357 cultivar showed profound increases in yield of dry seeds $(30.5 \%)$, as compared to control.
\end{abstract}

\section{INTRODUCTION}

Production of highly quality faba bean yield in northern Iraqi under rainfall incidences is possible in years of heavy rainfalls, particularly in March and April, however, precise cultural practices and growth improvement factors are required (Abdel, 1997). Droughted plants develop root system that are larger than their shoots and the moisture collected by extensive root is dawn up on for the consumption a reduced shoots (Batanouny , 2001). Morphological plasticity may increase the competitive ability of a plant over a range of different resources availabilities (Aert, et al., 1991). Growth regulators such as auxins, alar and cultar have been found to improve water stress resistance in faba bean and other crops (Attiya et al., 1989; El-Gamal, 1994 and Abdel, 1997).Thus, attempts were made to improving drought resistance of indeterminate Aquadulce, Local Syrian, Babylon and determinate Taka357 faba bean cultivars by the foliar spraying of different rates of either B9, Cultar, IBA or NAA.

\section{MATERIALS AND METHODS}


These experiments were carried out at the Horticultural field of research, Agriculture \& Forestry College, Mosul University during 2004-2005 growing season.

Received 30/11/2005 Accepted / /2006

Seeds of four faba bean cultivars namely Aquadulce, Local Syrian, Babylon and Taka 357 were obtained from the International Center for Agricultural Research in the dry areas (ICARDA), Aleppo, Syria; Agricultural Research Center, Mosul and Iraqi Atomic Energy Organization, Baghdad. Four growth regulators were sprayed twice with in 2 weeks intervals on faba bean plants, started with the commence of flowering, to investigate their ability of enhancing drought resistance of four faba bean cultivars by foliar spraying of $\mathrm{N}$-dimethylaminosuccinamic acid ( alar, B9) rates 0, 250, 500, 750 or 1000 mg. $I^{-1}$ in Aquadulce; $\beta$-[(4-chlorophenyl)]- $\alpha$-(1,1-dimethyl ethyl)-1H 1,2,4triazole-1-ethanol (Cultar) rates 0, 5075 or $100 \mathrm{mg} . \mathrm{L}^{-1}$ in Local Syrian; indole-3-butyric acid (IBA) rates $0,50,75$ or $100 \mathrm{mg} \cdot \mathrm{L}^{-1}$ in Babylon and naphthalene acetic acid (NAA) rates $0,25,50$ or $75 \mathrm{mg} . \mathrm{L}^{-1}$ in Taka357.

The rates of each of the 4 chemical compounds were separately experienced in a Randomized Complete Block Design (RCBD) trail. Each treatment was replicated three times and each replicate was represented by 104 plants raised on both sides of a furrow (5Xo.8m) with intra hills space of $(20 \mathrm{~cm}), 2$ plants per hill.

Field soil was clay of 56.4 clay, 12.3 sand and 31.3 silt of $21.8 \%$ field capacity , 12.9 wilting point and 1.6 g.cm-3 bulk density. One gypsum block was settled at $25 \mathrm{~cm}$ depth from top surface of the furrow to track soil moisture fluctuation during the growing season (Ruggiero et al., 1999). After a considerable rain falls on December, 10,2004 four seeds were sown in each pit , then plants were thinned to 2 plants per pit on January, 3rd , 2005. Thereafter, di-ammonium phosphate (DAP) was immediately applied at rate of $20 \mathrm{~g} . \mathrm{m}^{-2}$ and was repeated again on March, 3rd, 2005. At flowering stage, plants had a protective spray of benomyl fungicide at rate of $1 \mathrm{~g} . \mathrm{I}^{-1}$. At the commence of flowering stage on March, $3^{\text {rd }}, 2005$, each replicate of the 4 experiments was sprayed with its corresponding chemical rate and spraying was repeated after 2 weeks. Continuous weed eradications and other cultural practices were manually made. All experiments were terminated on May 5-15 ${ }^{\text {th }}, 2005$.

Data on plant height, number of branches on main stem, shedding leaves on main stem, leaflet numbers per leaf, first fruiting node, inflorescence numbers per main stem, pod numbers per plant, pod length, leaflet length and leaflet width were recorded. Leaflet area was calculated from leaflet length and width through linear regression ( Abdel, 1994). Leaflet samples were weighed and incubated in $100 \%$ relative humidity for $24 \mathrm{~h}$, then they were wiped by a piece of clothes and weighed thereafter, they were oven-dried at $60 \mathrm{C}^{\circ}$ for $72 \mathrm{~h}$. and their dry weights were recorded to calculate the leaflet water saturation 
deficit (WSD) and leaflet dry matter percentages. Light Microscope of (7x40) magnification, micrometric slides and graded lens were used to measure stomata characteristics (Abdel, 1997). Harvested plants were sun-dried for a week, then they were weighed, pod collected and weighed, thereafter, aborted ovules per pod, aborted seeds per pod and seeds per pod were counted. Finally, 100 seeds and yield of dry seeds. $\mathrm{m}^{-2}$ were weighed. Meteorological data (Figure, 1 and Table, 1), during faba bean growing season were obtained from Al-Rashidia Meteorological Station, Mosul City, IRAQ.

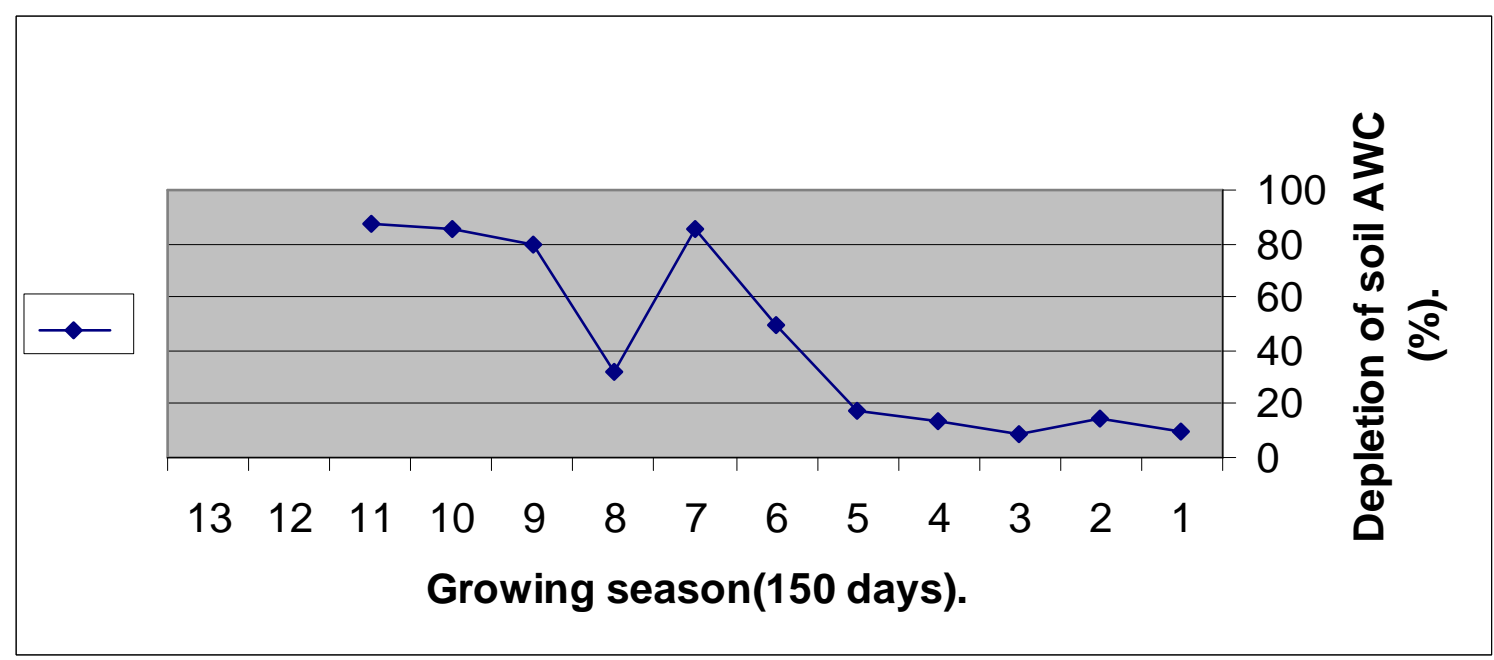

Figure ( 1 ): fluctuation of Soil AWC depletion percentages during the growing season

Table (1): Meteorological data during the growing season.

\begin{tabular}{|l|c|c|c|c|}
\hline Months & Minimum $\mathrm{C}^{\circ}$ & Maximum $\mathrm{C}^{\circ}$ & Relative Humidity (\%) & Rainfalls (mm) \\
\hline December & 6.5 & 13.1 & 84 & 82.2 \\
\hline February & 5.1 & 12.4 & 81 & 88.6 \\
\hline January & 4.1 & 16.7 & 68 & 62.5 \\
\hline March & 5.7 & 21.5 & 58 & 20.5 \\
\hline April & 12.3 & 26.8 & 48 & 71.4 \\
\hline May & 17 & 34.2 & 34 & 37 \\
\hline
\end{tabular}

\section{RESULTS AND DISCUSSION}

The effects of alar: Results in table (2), show the desired positive correlations which were obtained from the spraying of alar rates on Aquadulce cultivar plants in branches per plant $(r=0.58 *)$, leaflet dry matter percentage $(r=0.4)$, pod dry weight $(r=0.05)$, yield of dry, seeds $(r=0.034)$ and stomata numbers at upper and lower leaflet surfaces $(r=0.086$ and 0.25 , respectively). Furthermore, they also manifested other desired negative correlations in shedding leaf numbers on main stem $(\mathrm{r}=-0.031)$, first fruiting node $(\mathrm{r}=-0.21)$, aborted ovules per pod $(r=-0.26)$, aborted seeds per pod $(r=-0.095)$, stomata length at upper leaf surface $(r=-0.25)$, aperture length of upper leaf surface stomata $(r=-0.0068)$ and aperture width of leaf lower surface stomata $(r=-$ $\left.0.5^{*}\right)$. The positive and negative correlations explained the ability of alar rates 
in ameliorating the drastic effects of drought episodes. Undesired negative correlations were found in plant height $\left(\mathrm{r}=-0.7^{* *}\right)$, leaf numbers on main stem $(\mathrm{r}=-0.49 *), \quad$ leaf $\quad$ area index $(\mathrm{r}=-0.72 * *)$ inflorescence numbers on main stem $(\mathrm{r}=-0.082)$, pod numbers per plant $(\mathrm{r}=-0.17)$, seeds per pod $(\mathrm{r}=-0.42)$ and weight of 100 seeds $(\mathrm{r}=-$ $0.48 *)$. Undesired positive correlation were also observed in aperture width of leaf upper surface stomata alar $(\mathrm{r}=0.043)$, and aperture length of leaf lower surface stomata $(\mathrm{r}=0.44) .250 \mathrm{mg} . \mathrm{L}^{-1}$ was the paramount treatment in relation to other rates particularly to untreated check. It increased pod dry weight (39.1\%0, weight of 100 seeds $(7.2 \%)$ and yield of dry seeds $(52.8 \%)$. Besides, it improved stomata characteristics and behaviors to sustain gas exchange good, through increasing stomata populations at both upper and lower

Table (2). The effects of alar rates on growth and yield of Aquadulce cultivar

\begin{tabular}{|c|c|c|c|c|c|c|c|c|}
\hline \multirow{2}{*}{ Parameters (Y) } & \multicolumn{5}{|c|}{ Alar rates mg. $\mathrm{L}^{-1}(\mathrm{X})$} & \multicolumn{3}{|c|}{ Linear equations $(\mathrm{y}=\mathrm{a}+\mathrm{bx})$. } \\
\hline & 0.0 & 250 & 500 & 750 & 1000 & $\mathrm{a}$ & $\mathrm{b}$ & $\mathrm{R}$ \\
\hline Plant height $(\mathrm{cm})$ & 44.5 & 42.2 & 41 & 39.6 & 38.3 & 44.10 & -0.006 & $-0.70 * *$ \\
\hline Branches nos./plan & 3.8 & 4.6 & 4.6 & 4.8 & 5.2 & 4.02 & 0.0010 & $0.580^{*}$ \\
\hline Leaf nos./ main stem & 14.9 & 13.7 & 14.9 & 13.9 & 13.1 & 14.77 & -0.0014 & $-0.490^{*}$ \\
\hline Shedding leaf/main stem & 6.1 & 6.5 & 5.8 & 5.7 & 6.4 & 6.12 & -0.0001 & -0.031 \\
\hline Leaflet nos./leaf & 6.5 & 6.1 & 6.1 & 5.9 & 6 & 6.37 & -0.0005 & -0.440 \\
\hline Leaflet area $\left(\mathrm{cm}^{2}\right)$ & 0.2 & 6.5 & 7 & 6.6 & 6.7 & 7.49 & -0.0010 & -0.280 \\
\hline Leaf area index & 2.0 & 1.3 & 1.3 & 1.2 & 1.3 & 1.72 & -0.0006 & $-0.72 * *$ \\
\hline Leaflet dry mat & 12.6 & 12.1 & 12 & 14.6 & 14.9 & 11.70 & 0.00200 & 0.400 \\
\hline Pod nos./plant & 5.6 & 4.2 & 4.4 & 4.9 & 4.5 & 4.99 & -0.0006 & -0.330 \\
\hline Pod lens & 12.1 & 10.9 & 11.1 & 11.7 & 11.1 & 11.64 & -0.0005 & -0.170 \\
\hline Aborted ovt & 2.7 & 1.7 & 2.7 & 2 & 2 & 2.40 & -0.0004 & -0.260 \\
\hline Aborted seeds/ & 1.7 & 1.3 & 1.7 & 1.7 & 1.3 & 1.60 & -0.0001 & -0.095 \\
\hline Seed nos./pod & 3.1 & 2.7 & 2.7 & 2.6 & 2.4 & 2.95 & -0.0005 & -0.420 \\
\hline Plant dry weight & 137.5 & 189.6 & 100 & 116.7 & 152.1 & 147.94 & -0.0180 & -0.100 \\
\hline Pod dry weight (g.m $\left.{ }^{-2}\right)$ & 84.4 & 117.4 & 74 & 90.6 & 102.7 & 91.89 & 0.0039 & 0.0500 \\
\hline Weight of 100 & 104.3 & 111.8 & 98.9 & 96.7 & 99.5 & 107.16 & -0.0100 & $0.480 *$ \\
\hline Dry seed Yield (g.m $\left.{ }^{-2}\right)$ & 69.1 & 105.6 & 72.8 & 79.0 & 84.9 & 81.29 & 0.0020 & 0.034 \\
\hline First fruiting node & 4.8 & 5.0 & 4.6 & 4.6 & 4.7 & 4.84 & -0.0002 & -0.082 \\
\hline Inflores. no./main stem & 6.0 & 4.9 & 5.8 & 6.1 & 5.2 & 5.70 & -0.0002 & -0.210 \\
\hline Setting (\%) & 24.1 & 28.5 & 32.3 & 26.2 & 27.6 & 26.80 & 0.00180 & 0.1400 \\
\hline St po up su/mm $/ \mathrm{mm}^{-2} \times 10^{-2}$ & 17.5 & 16.4 & 19.6 & 18.4 & 20.6 & 16.84 & 0.3300 & $0.490^{*}$ \\
\hline St po lo $\mathrm{su} / \mathrm{mm}^{-2} \times 10^{-2}$ & 22.4 & 18 & 24.8 & 21.1 & 27.00 & 20.18 & 0.4900 & 0.3700 \\
\hline St le up su (micron) & 9.8 & 9.1 & 9.2 & 9.8 & 9.40 & 9.49 & -0.0001 & -0.020 \\
\hline St le lo su (micron) & 9.8 & 10.3 & 11.5 & 11.2 & 9.90 & 10.27 & 0.0005 & 0.2500 \\
\hline St wid up su (micron) & 9.7 & 9.3 & 8.5 & 9.8 & 8.00 & 8.56 & 0.0003 & 0.0860 \\
\hline St wid lo su (micron) & 10.3 & 9.5 & 8.3 & 9.3 & 7.30 & 10.23 & -0.0026 & $-0.540^{*}$ \\
\hline St ap le up su (micron) & 5.1 & 3.9 & 4.3 & 5.0 & 4.50 & 4.53 & 0.00001 & -0.0068 \\
\hline St ap le lo su (micron) & 4.5 & 5 & 6.6 & 5.8 & 5.30 & 4.97 & 0.00100 & 0.4400 \\
\hline & 2.4 & 2.9 & 3.4 & 3.3 & 2.30 & 2.83 & 0.00010 & 0.0340 \\
\hline St ap wid lo su (micron) & 4.5 & 3.6 & 2.8 & 3.7 & 2.00 & 4.27 & -0.0020 & $0.510^{*}$ \\
\hline
\end{tabular}

Note: St=stomata; le=length; up=upper; lo=lower; ap=aperture; su=surface; po=population; wid=width 
leaf surfaces and decreasing their dimensions in relation to their corresponding checks. Very close results were found by (Abdel, 1997), although he applied alar earlier at the vegetative stage of faba bean. However, application of alar at the flowering stage is more potent than its application quite early at vegetative stage. Application of alar at the flowering stage where the plant growth is almost fulfilled, its potent action will experience on the up coming growth which is usually synchronized with low rainfall incidences late in the season. Moreover, the late period of faba bean growing season is accompanied by gradual temperature increases and a high water consumptive use. The increases of stomata population as a results of drought and alar application is a paradoxical phenomenal, the fact is drought and growth inhibitors tend to reduce the leaf area and cell elongation, however, cell division is slightly influenced, Therefore the initial numbers of stomata on leaf primordial are maintained during leaf expansion and development period, ultimately the unit area of the experienced leaf will contains a huge numbers of stomata in comparison to that of well irrigated leaf. Thus air- plant continuum is improved and these improvements were reflected on sink-source and latter on yield of dry seeds. Reductions in leaf area caused by alar application might be substituted by the tendency of alar to increase branch numbers per plant and ultimately the leaf area index is increased ( Table 2). Our results are in agreement with those obtained by ( McEwen, 1973 and El-Beltagy et al., 1979). Alar mode of action is achieved by its conversion to tryptamine in plant cell with the aid of diamine oxidase (Reed, et al., 1965). Alar is implicated in boosting IAA oxidase (Halevy, 1963), and inhibiting the oxidation of ent-kaurenoic acid to form ent7 - $\alpha$-kaurenoic acid which is the most important step in the synthesis of GA12 aldehyde (Goodwin, and Mercer, 1985).

The effects of cultar: Table (3) results showed that the applied cultar rates displayed desired positive and negative correlations to explain the high ability of cutar rates in the improvement of drought avoidance. Therefore, positive correlations were obtained in number of branches per plant $(\mathrm{r}=0.69 *)$, leaflet number per leaf $(\mathrm{r}=0.0074)$, leaf area index $\left(\mathrm{r}=0.6^{*}\right)$, pod per plant $(\mathrm{r}=0.14)$, seeds per pod $(\mathrm{r}=0.33)$, pod dry weight $(\mathrm{r}=0.49)$, yield of dry seeds $(\mathrm{r}=0.51)$ and stomata populations at both upper and lower surfaces of leaf $(=0.81 * *$ and $0.74 * *$, respectively). Furthermore, negative correlations favorable for enhancing drought resistance of Local Syrian cultivar were also observed in shedding leaf numbers on main stem $(\mathrm{r}=-0.12)$, leaflet water saturation deficit $\left(\mathrm{r}=-0.84^{* *}\right)$, aborted ovules per pod $\left(\mathrm{r}=-0.57^{*}\right)$, aborted seeds per pod $(\mathrm{r}=-0.4)$ stomata length at leaf lower surface $\left(\mathrm{r}=-0.56^{*}\right)$, stomata width at leaf upper surface $\left(\mathrm{r}=-0.61^{*}\right)$, aperture length of leaf upper surface stomata $(\mathrm{r}=-0.15)$ and aperture width of upper surface stomata $(\mathrm{r}=-0.74 *)$. However, undesired negative and positive correlations were detected in plant height $(\mathrm{r}=-0.3)$, leaf numbers on main stem $(\mathrm{r}=-0.18)$, pod length $(\mathrm{r}=-0.12)$, plant dry weight $(\mathrm{r}=-$ $\left.0.64^{*}\right)$, stomata length at upper leaf surface $(r=0.46)$ and aperture width of leaf lower surface stomata $(\mathrm{r}=0.036) .50 \mathrm{mg} . \mathrm{L}^{-1}$ rate was the most effective treatment. It resulted in increases of $32.4,4.7,74,62.2$ and $48.4 \%$, respectively 
, in number of branches per plant, leaflet numbers per leaf, leaf area index, pod dry weight and yield of dry seeds as compared to its corresponding checks. Moreover, it showed apparent reductions in aborted ovule per pod, aborted seeds per pod, stomata length at leaf lower surface, stomata width at leaf upper surface and aperture width of upper leaf surface stomata by 22.7, 83, 9, 10, and $19.2 \%$, respectively, in relations to untreated controls (table, 3 ).

Very close results were obtained with foliar applications of cultar in earlier stages of vegetative growth of Aquadulce cultivar in reference to cold and drought

resistance ( Abdel, 1997). The results of this investigation showed that the application of cultar at the commence of flowering stage were more useful in case of resisting drought alone, since earlier application is usually concomitant by cultar disintegration resulted in its gradual by time dilution in plant tissue. Thereafter, inactive tissues content of cultar will be synchronized during the ensuing drought incidences. Attiya et al. (1989) found that foliar spraying of cultar gave significant reductions in vegetative and reproductive parameters which resulted in rearrangements of photosynthetic assimilates distribution. In sweet potato, cultar application also resulted in significant growth reductions accompanied by high root yield of improved nutritional values (El-Gamal, 1994). Improving air - plant continuum by modifying stomata dimensions which is usually confined by reducing transpiration and sustaining adequate $\mathrm{Co}_{2}$ entrance to leaflet mesophyll to keep fair enough photosynthesis rate is the most acceptable interpretation for the yield improvement in cultar treated faba bean. Application of cultar was found to increase cuticle thickness of epidermal cells, stomata populations, decreasing cell sizes, reducing intercellular spaces, delaying senescence, improving the resistance to drought and cold stresses ( Swietlik and Miller, 1983; Mc Arthur and Eton, 1987 and Abdel, 1997).

Table (3). The effects of cultar on growth and yield of Local Syrian cultivar.

\begin{tabular}{|c|c|c|c|c|c|c|c|}
\hline \multirow{2}{*}{ Parameters (Y) } & \multicolumn{4}{|c|}{ Cultar rates g.L $\mathrm{L}^{-1},(\mathrm{X})$} & \multicolumn{3}{|c|}{ Linear equations $(\mathrm{y}=\mathrm{a}+\mathrm{bx})$} \\
\hline & 0.0 & 50 & 75 & 100 & $\mathrm{a}$ & $\mathrm{b}$ & $r$ \\
\hline Plant height $(\mathrm{cm})$ & 42.0 & 40.6 & 38.8 & 39.3 & 41.90 & -0.0300 & -0.300 \\
\hline Branches nos./plan & 4.6 & 6.8 & 6.1 & 7.2 & 4.89 & 0.0230 & $0.69 * *$ \\
\hline Leaf nos./ main stem & 15.0 & 15.8 & 14.9 & 14.6 & 15.32 & -0.0040 & -0.180 \\
\hline Shedding leaf/main stem & 6.0 & 6.0 & 5.5 & 5.8 & 6.04 & -0.0040 & -0.180 \\
\hline Leaflet nos./leaf & 5.4 & 5.8 & 5.3 & 5.5 & 5.51 & 0.00010 & 0.0074 \\
\hline Leaflet area $\left(\mathrm{cm}^{2}\right)$ & 4.7 & 5.1 & 6.3 & 4.3 & 5.05 & 0.0013 & 0.0530 \\
\hline Leaf area index & 1.2 & 2.1 & 2.0 & 1.7 & 1.43 & 0.0057 & $0.600^{*}$ \\
\hline Leaf WSD (\%) & 61.6 & 42.6 & 36.8 & 30.0 & 60.54 & -0.320 & $-0.84 * *$ \\
\hline Leaflet dry matter $(\%)$ & 15.4 & 17.3 & 13.8 & 12.4 & 16.5 & -0.0310 & -0.32 \\
\hline Pod nos./plant & 7.3 & 5.9 & 8.1 & 7.5 & 6.9 & 0.0059 & 0.14 \\
\hline Pod length $(\mathrm{cm})$ & 7.8 & 7.7 & 7.2 & 7.7 & 7.7 & -0.0025 & -0.12 \\
\hline Aborted ovules/pod & 2.7 & 2.2 & 2.8 & 2.5 & 3.4 & -0.011 & $-0.57 *$ \\
\hline Aborted seeds/pod & 2.2 & 1.2 & 1.3 & 1.7 & 1.9 & -0.0060 & -0.40 \\
\hline Seed nos./pod & 1.7 & 2.6 & 2.0 & 2.0 & 1.7 & 0.0036 & 0.33 \\
\hline
\end{tabular}




\begin{tabular}{|c|c|c|c|c|c|c|c|}
\hline Plant dry weight $\left(\mathrm{g} \cdot \mathrm{m}^{-2}\right)$ & 597.4 & 434.8 & 364.7 & 353.9 & 566.8 & -2.370 & $-0.64 *$ \\
\hline Pod dry weight (g.m ${ }^{-2}$ ) & 66.7 & 108.2 & 90 & 97.5 & 74.9 & 0.2800 & 0.49 \\
\hline Weightof 100 seeds $(\mathrm{g})$ & 100.7 & 105.1 & 105.1 & 104.8 & 101.5 & 0.0430 & 0.23 \\
\hline dry seed Yield $\left(\mathrm{g} . \mathrm{m}^{-2}\right)$ & 59.9 & 89.1 & 74.0 & 85.1 & 64.9 & 0.2200 & $0.50 *$ \\
\hline St po up su/mm $/ \mathrm{mm}^{-2} \times 10^{-2}$ & 16.3 & 19.0 & 21.4 & 22.0 & 16.3 & 5.9700 & $0.81 * *$ \\
\hline St po lo su/mm $/ \mathrm{mm}^{-2} \times 10^{-2}$ & 20.0 & 23.7 & 30.1 & 30.4 & 96.4 & 11.4500 & $0.74 * *$ \\
\hline St le up su (micron) & 8.9 & 9.3 & 9.7 & 9.4 & 9.0 & 0.0066 & 0.46 \\
\hline St le lo su (micron) & 10.9 & 10.0 & 10.2 & 9.4 & 10.9 & -0.0130 & $-0.56^{*}$ \\
\hline St wid up su (micron) & 8.5 & 7.7 & 8.3 & 6.8 & 8.6 & -0.0130 & $-0.61 *$ \\
\hline St wid lo su (micron) & 7.8 & 7.5 & 8.1 & 7.1 & 7.8 & -0.0038 & -0.20 \\
\hline St ap le up su (micron) & 4.8 & 4.7 & 4.7 & 5.4 & 4.6 & 0.0050 & 0.42 \\
\hline St ap le lo su (micron) & 6.5 & 6.7 & 7.8 & 5.2 & 6.9 & -0.0057 & -0.15 \\
\hline St ap wid up su (micron) & 3.1 & 2.6 & 2.5 & 2.2 & 3.1 & -0.010 & $-0.74 * *$ \\
\hline St ap wid lo su (micron) & 2.2 & 2.5 & 2.5 & 2.2 & 2.4 & 0.0004 & 0.360 \\
\hline
\end{tabular}

The effects of IBA: Data in table (4) revealed That IBA possesses a drought boosting tendency as its foliar application displayed desired positive and correlations in plant height $(r=0.26)$, leaflet numbers per leaf $(r=0.31)$, leaf area $(\mathrm{r}=0.21)$, leaf area index $(\mathrm{r}=0.28)$, setting percentage $(\mathrm{r}=0.04)$, pod length $(r=0.48)$, seed numbers per pod $(r=0.29)$, plant dry weight $(r=$ $\left.0.69^{*}\right)$,pod dry weight $\left(\mathrm{r}=0.56^{*}\right)$, weight of 100 seeds $\left(\mathrm{r}=0.68^{*}\right)$ and yield of dry seeds $(\mathrm{r}=0.46)$. Moreover it also showed desired negative correlations in shedding leaves on main stem $(r=-0.24)$, leaflet water saturation deficit $(r=-$ $0.63 *)$, first fruiting node $(\mathrm{r}=-0.002)$, aborted ovules per pod $(\mathrm{r}=-0.34)$ and aborted seeds per pod (=-0.27). $75 \mathrm{mg} . \mathrm{L}^{-1}$ rate was prevailed over other treatments. It exceeded untreated control in plant height $(6.8 \%)$, leaflet numbers per leaf $(12.3 \%)$, leaflet area $(22 \%)$, leaf area index $(49.1 \%)$, seed numbers per pod $(12.1 \%)$, plant dry matter $(31 \%)$, pod dry weight $(49.3 \%)$, weight of 100 seeds (13\%) and yield of dry seeds (86.4\%). Furthermore, it displayed reductions of $16,9,18.2$ and $66.7 \%$ in shedding leaves on main stem, leaflet water saturation deficit, aborted ovules per pod and aborted seeds per pod, respectively, in relation to its corresponding checks. Similar results were obtained by ( Abdel, data under publication), the gained improvements in drought resistance as a result of IBA foliar spray might be attributed to the influence of auxin on sink- source of assimilate and on enhancing flower fertilization and fruit set ( Kinet et al., 1985).

Table (4) The effects of IBA on growth and yield of Babylon cultivar.

\begin{tabular}{|l|c|c|c|c|c|c|c|}
\hline \multirow{2}{*}{ Parameters (Y) } & \multicolumn{4}{c|}{ IBA rates g. $\mathrm{L}^{-1},(\mathrm{X})$} & \multicolumn{3}{c|}{ Linear equations (y=a+bx). } \\
\cline { 2 - 9 } & 0.0 & 50 & 75 & 100 & $\mathrm{a}$ & $\mathrm{b}$ & $\mathrm{r}$ \\
\hline Plant height (cm) & 39.6 & 40.1 & 42.3 & 41.6 & 39.62 & 0.0200 & 0.260 \\
\hline Branches nos./plan & 4.0 & 4.8 & 4.6 & 4.2 & 4.29 & 0.0020 & 0.090 \\
\hline Leaf nos./ main stem & 14.4 & 12.1 & 13.7 & 13.3 & 13.52 & -0.0042 & -0.150 \\
\hline Shedding leaf/main stem & 5.7 & 6.1 & 4.9 & 6.6 & 5.87 & -0.0074 & -0.240 \\
\hline Leaflet nos./leaf & 5.7 & 5.0 & 6.4 & 6.0 & 5.50 & 0.0025 & 0.310 \\
\hline
\end{tabular}




\begin{tabular}{|l|c|c|c|c|c|c|c|}
\hline Leaflet area $\left(\mathrm{cm}^{2}\right)$ & 5.0 & 4.9 & 6.1 & 4.9 & 5.04 & 0.0030 & 0.210 \\
\hline Leaf area index & 1.1 & 1.0 & 1.6 & 1.1 & 1.08 & 0.0020 & 0.280 \\
\hline Leaf WSD $(\%)$ & 70.9 & 60.6 & 64.5 & 62.8 & 68.98 & -0.076 & $-0.63^{*}$ \\
\hline Leaflet dry matter (\%) & 14.4 & 14.1 & 13.6 & 13.6 & 14.10 & -0.084 & -0.450 \\
\hline Pod nos./plant & 5.8 & 3.8 & 5.4 & 4.9 & 5.33 & -0.0062 & -0.200 \\
\hline Pod length (cm) & 10.7 & 9.9 & 14.9 & 13.1 & 10.22 & 0.0340 & 0.480 \\
\hline Aborted ovules/pod & 2.6 & 2.7 & 2.2 & 1.9 & 2.71 & -0.0068 & -0.430 \\
\hline Aborted seeds/pod & 2.0 & 1.7 & 1.2 & 1.9 & 1.88 & -0.0031 & -0.270 \\
\hline Seed nos./pod & 3.3 & 2.9 & 3.7 & 3.7 & 3.09 & 0.0053 & 0.290 \\
\hline Plant dry weight(g.m $\left.{ }^{-2}\right)$ & 183.3 & 187.3 & 240.2 & 263.7 & 171.74 & 0.8300 & $0.69^{*}$ \\
\hline Pod dry weight (g.m $\left.{ }^{-2}\right)$ & 75.0 & 85.0 & 112 & 103.8 & 75.59 & 0.3200 & $0.56^{*}$ \\
\hline Weight of 100 seeds (g) & 91.5 & 100.0 & 103.7 & 103.8 & 92.50 & 0.1300 & $0.68^{*}$ \\
\hline dry seed Yield (g.m $\left.{ }^{-2}\right)$ & 61.0 & 68.2 & 113.7 & 83.2 & 61.83 & 0.3500 & 0.460 \\
\hline First fruiting node & 4.9 & 5.1 & 5.0 & 4.4 & 5.04 & -0.0040 & -0.23 \\
\hline Inflors. Nos./main stem & 5.5 & 4.2 & 5.5 & 5.3 & 5.14 & -0.00001 & -0.002 \\
\hline Setting (\%) & 32.5 & 37.8 & 36.1 & 30.8 & 34.66 & 0.0070 & 0.040 \\
\hline
\end{tabular}

The effects of NAA: Results in table (5) displayed desired positive correlations in plant height $(\mathrm{r}=0.12)$, number of branches per plant $(\mathrm{r}=0.44)$, leaflet number per leaf $(r=0.48)$ leaflet area $(r=0.39)$ leaf area index $\left(r=0.57^{*}\right)$, inflorescence numbers on main stem $(\mathrm{r}=0.11)$, pod length $(\mathrm{r}=0.19)$, pod number per plant $(=0.12)$, seed numbers per pod $(\mathrm{r}=0.26)$, plant dry weight $(\mathrm{r}=0.087)$ and weight of 100 seeds $(\mathrm{r}=0.26)$. Moreover, desired negative correlations were also found in shedding leaves on main stem $(\mathrm{r}=-0.39)$ aborted ovules per pod $(\mathrm{r}=0.16)$, aborted seeds per pod $(\mathrm{r}=-0.53)$. The desired positive and negative correlations gained by the foliar application of NAA explained the tendency of NAA in improving drought resistance of Taka 357 cultivar, despite the undesired negative and positive correlations that emerged in the pod dry weight $(\mathrm{r}=-0.31)$, leaves numbers on main stem $(\mathrm{r}=-0.25)$, yield of dry seeds $(\mathrm{r}=-0.22)$ and First fruiting node ( $\mathrm{r}=0.24)$. Rate of $25 \mathrm{mg} . \mathrm{L}^{-1}$ treatment tended to increase plant height $(23.3 \%)$, number of branches per plant $(76.5 \%)$, leaflet numbers per leaf $(8.1 \%)$, leaf area index $(15.4 \%)$, pod numbers per plant $(60.8 \%)$, seed numbers per pod (15.4\%), plant dry weight (27.2\%), weight of 100 seeds $(10.4 \%)$ and yield of dry seeds (30.5\%). In addition to that, it showed reductions of $47,43.5$ and $15 \%$ in shedding leaves on main stem, aborted ovules per pod and aborted seeds per pod, respectively, when it was compared to its corresponding controls. The obtained results suggested that there were no doubt about NAA enhancement of drought resistance in faba bean, but the problem was in the tested determinate Taka357 cultivar which displayed a huge gap in growth and yield under severe drought episodes, particularly in the yield of dry seeds (28.9 g.m-2) in comparison to other cultivars for instance Aquadulce (116.7 g.m-2). Five faba bean cultivar including Aquadulce and Taka357 were evaluated for drought resistance, they resulted in very close drought resistance ability to that found in this investigation (El-Hamadany, 
2005). Drought susceptibility in determinate growth habit cultivars including Taka357 might be referred to the photosynthetic rate and assimilate distribution. Determinate faba bean cultivars possesses a major source-sink which

Table (5) The effects of NAA rates on growth and yield of Taka357 cultivar.

\begin{tabular}{|c|c|c|c|c|c|c|c|}
\hline \multirow[t]{2}{*}{ Parameters (Y) } & \multicolumn{4}{|c|}{ NAA rates $g .1^{-1},(\mathrm{X})$} & \multicolumn{3}{|c|}{$\begin{array}{l}\text { Linear equations } \\
\quad(y=a+b x)\end{array}$} \\
\hline & 0.0 & 25 & 50 & 75 & $\mathrm{a}$ & $\mathrm{b}$ & $r$ \\
\hline Plant height $(\mathrm{cm})$ & 21 & 25.9 & 22 & 22.7 & 22.7 & 0.0088 & 0.120 \\
\hline Branches nos./plan & 3.4 & 6.0 & 5.6 & 5.5 & 4.3 & 0.0240 & 0.440 \\
\hline Leaf nos./ main stem & 8.5 & 7.4 & 6.1 & 7.8 & 8.0 & -0.013 & -0.340 \\
\hline Shedding leaf/main stem & 6.5 & 4.4 & 4.3 & 4.8 & 5.8 & -0.020 & -0.390 \\
\hline Leaflet nos./leaf & 3.7 & 4.0 & 4.1 & 4.1 & 3.8 & 0.0053 & 0.480 \\
\hline Leaflet area $\left(\mathrm{cm}^{2}\right)$ & 8.4 & 14.8 & 12.5 & 13.2 & 10.4 & 0.0480 & 0.390 \\
\hline Leaf area index & 0.6 & 1.76 & 1.16 & 1.55 & 0.9 & 0.0090 & $0.570 *$ \\
\hline First fruiting node & 4.3 & 4.2 & 4.4 & 4.6 & 4.2 & 0.0040 & 0.240 \\
\hline Inflors. Nos./main stem & 4.0 & 3.5 & 3.8 & 4.1 & 3.8 & 0.0024 & 0.110 \\
\hline Setting $(\%)$ & 37.1 & 55.3 & 42.5 & 36.3 & 45.1 & -0.060 & -0.160 \\
\hline Pod nos./plant & 2.3 & 3.7 & 3.5 & 2.7 & 2.9 & 0.004 & 0.120 \\
\hline Pod length $(\mathrm{cm})$ & 11.8 & 13.6 & 12.9 & 13 & 12.4 & 0.012 & 0.190 \\
\hline Aborted ovules/pod & 3.3 & 2.3 & 2.3 & 3.0 & 2.9 & -0.004 & -0.160 \\
\hline Aborted seeds/pod & 2.3 & 2.0 & 1.7 & 1.7 & 2.3 & -0.0093 & $-0.53 *$ \\
\hline Seed nos./pod & 2.6 & 3.0 & 3.0 & 3.0 & 2.3 & 0.0049 & 0.260 \\
\hline Plant dry weight $\left(\mathrm{g} \cdot \mathrm{m}^{-2}\right)$ & 102.9 & 161.8 & 138.9 & 123.5 & 125.9 & 0.1500 & 0.087 \\
\hline Pod dry weight (g.m²) & 40.1 & 51.0 & 35.7 & 36.2 & 44.8 & -0.1100 & -0.310 \\
\hline Weight of 100 seeds $(\mathrm{g})$ & 97.2 & 107.3 & 107.3 & 103.6 & 101.0 & 0.0770 & 0.260 \\
\hline dry seed Yield (g.m²) & 28.9 & 37.7 & 26.2 & 27.9 & 32.3 & -0.060 & -0.220 \\
\hline
\end{tabular}

concentrated in middle portion of the plant stem where the most pod are borne and all photosynthate are channeled to this single dominant sink which get filled in synchronized manner giving a determinate habit (Kagure, 1993). Slim, et al., (1993) reported that early flowering is probably the characteristics widely used by breeder for cereals and food legumes in semi-arid environment, as it has been considered the main requirement for obtaining a good yield in dry areas of Asia and North Africa region. This finding is quite true unless, the rainfall is not ceased early and drought is synchronized with pod development and seeds filling, as that of this growing season (figure,1). However, earlier maturation was considered as drought escapable characteristic ( Abdel, 1982 and El-Hamadany, 2005), active participation of pods in photosynthesis of determinate cultivar, owing to their direct exposure to sun light (Chapman and Peat, 1978 ) and small plan size were not helpful in confronting drought adverse effects on determinate Taka357 cultivar.

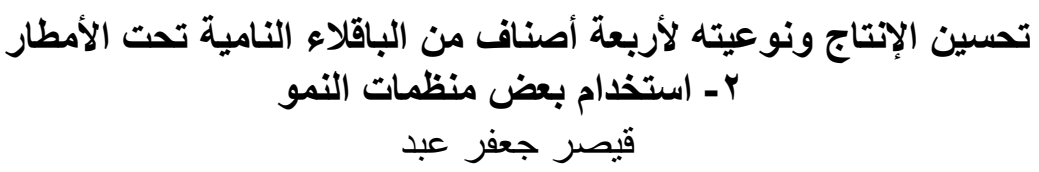


قسم البستنة و هندسة الحدائق ، كلية الزر اعة و الغابات ، جامعة الموصل ، العراق

الخلاصة

أجريت أربعة تجارب في حقل الأبحاث التابع لقسم البستنة و هندسـة الحدائق ، كليـة الزر اعـة

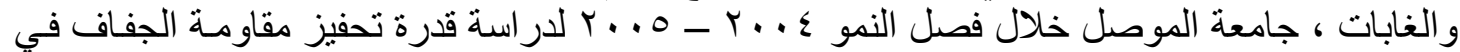

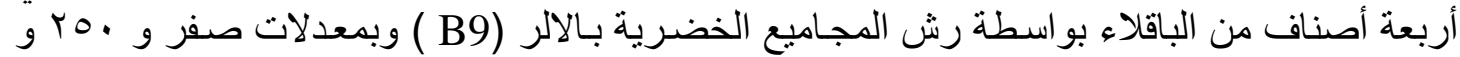

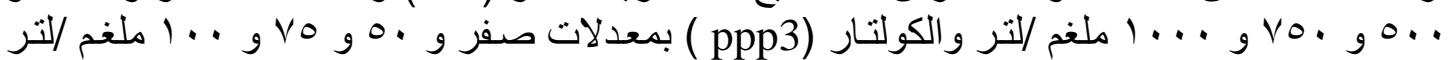

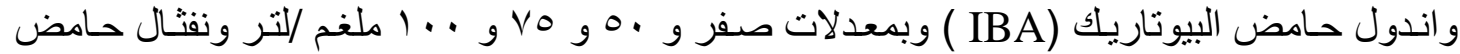

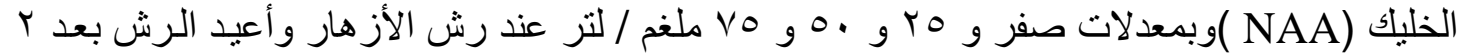

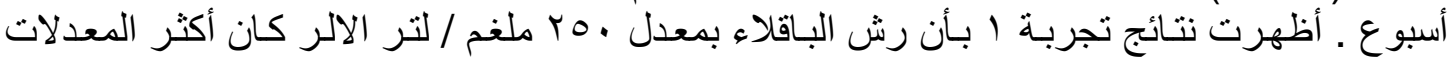

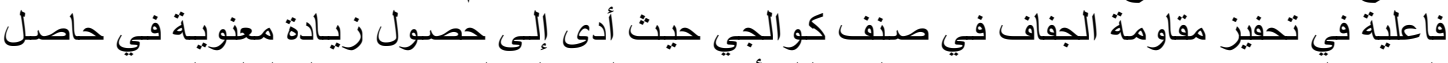

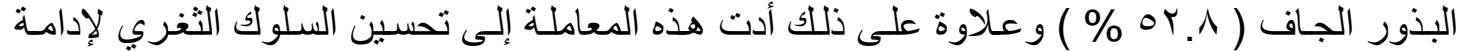

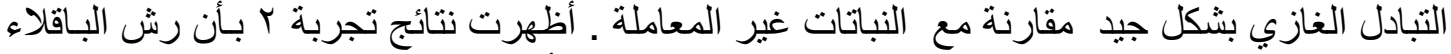

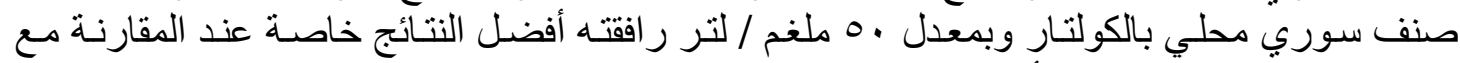

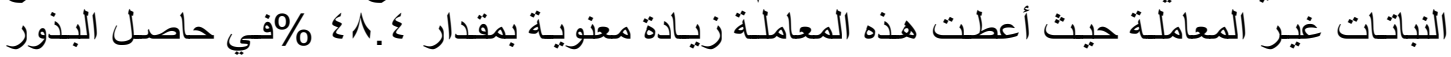

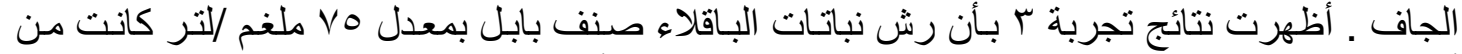

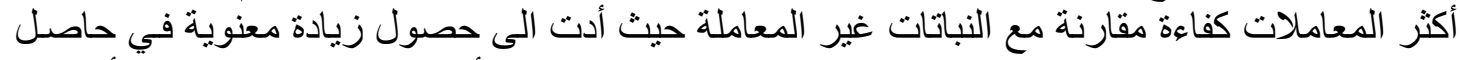

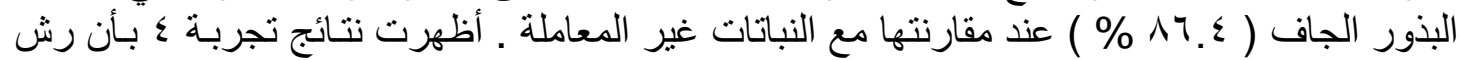

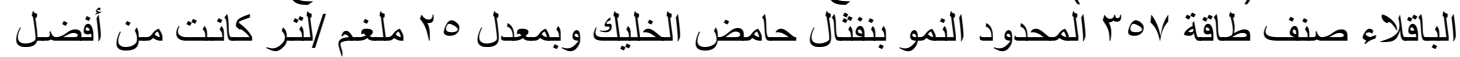

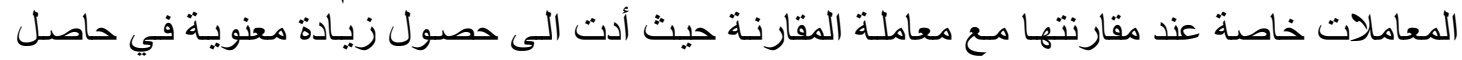

\section{REFERENCES}

البذور الجاف (0. • م \%).

Abdel, C. G. (1982). Drought resistance in (Vicia faba L.): A study of four cultivars.Msc Thesis, Bath University, England, UK.

Abdel, C. G. (1994). Rapid methods for estimating leaf area and size in field bean (Vicia faba L.). Tech. Res. 7 ( 20): 63-70.

Abdel, C. G. (1997). Physiological studies on growth, flowering, fruit setting and yield of faba bean (Vicia faba L.). PhD Thesis, Mosul University, Mosul, Iraq.

Aerts, R.; R. G. A. Boot and P. J. M. Vander Art (1991). The relation between above and belowground biomass allocation patterns and competitive ability. Oecologia (Berlin) 87:551-559.

Attiya, H. J.; K. S. Jabour and R. M. El-Mola (1989).Response of field bean local cv. To some growth regulators. $5^{\text {th }}$. Sci Conf. of Sci. Res. Council, Baghdad, 7-11October 1 (5): 110-118.

Batanouny, K. H. (2001). Plants in the desert of middle east. ISSN 143094322. pringler Pub.

Chapman, G. P. and W. E. Peat (1978). Procurement of yield of field and broad bean. Outlook in Agric. 2: 262 - 272.

El-Beltagy, A. S. ; M. S. El-Beltagy and M. A. Hall (1979). Modification of vegetative development, flowering and fruiting behavior in (Vicia faba L.) by treatment with growth regulators. Egypt J. Hort. 6: 237-260.

El-Gamal, A. M. (1994). Effect of paclopbutrazole, a plant growth retardant levels on sweet potato yield and root quality. Aex J. Agric. Res: 39 (2): 379-86. 
El-Hamadany, S. H. (2005). The effects of supplemental Irrigation and Abscisic acid (ABA) spraying on growth and yield of some faba bean (Vicia faba L.) cultivars. PhD Thesis, Mosul University, Mosul, Iraq.

Goodwin, T. W. and E. I. Mercer (1985). Introduction to plant biochemistry. $2^{\text {nd }}$ ed. Pergamon Press.

Halevy, A. H. (1963). Interaction of growth retarding compounds and gibberellins on indole acetic acid oxidase and peroxidase of cucumber seedlings. Plant Physiol. 38: 371-37.

Kagure, K. (1993).Some physiological studies on faba bean in Japan. In M. C. Saxena; S. Weigand and L. Li-Juan (1993) Faba bean production and research in China. ICARDA, Aleppo, Syria.

Kient, J. M.; R. M. Sachs and G. Beriner (1985). The Physiology of Flowering. Vol. II, CRS Press Inc.

McArthur, D. A. J. and G. W. Eton (1987). Effect of fertilizer, paclobutrazol and chloromequat on strawberry.J. Amer. Soc. Hort. Sci. 112 (2): 241-46.

McEwen, J. (1973). The effect of growth regulators, seed rates and row spacing on field beans (Vicia faba L.). J. Agric. Sci. Cab. 80: 12-37.

Reeds, D. J.; T. G. Moore and J. D. Anderson (1965). Plant growth retardant B995: A possible mode of action . Science:148, 1469-71.

Ruggiero, C.; S. Depascale and M. Fagnano (1999). Plant and soil resistance to water flow in faba bean (Vicia faba L. Major Harz). Plant and Soil 210 (2): 381-391.

Slim, S. N.; M. C. Saxena and W. Erskine (1993). Adaptation of lentil to Mediterranean environment. 1- factors affecting yield under drought condition. Environmental Agriculture 29.

Swietlik, D. and S. S. Miller (1983). The effect of paclobutrazol on growth and response to water stress of apple seedling. J. Amer. Soc. Hort. Sci.108 (6): 1076-80. 